\title{
A Study on Factors Influencing the Job Satisfaction of Bank Employees in Nepal (With special reference to Kathmandu, Lalitpur, and Bhaktapur District)
}

\author{
Bashu Neupane \\ Lecturer \\ Nepal Commerce Campus, Faculty of Management, T.U.
}

\begin{abstract}
Job satisfaction means the positive feeling or attitude that employees have towards their job, which acts as a motivation to work. It is a combination of emotion, belief, feeling, sentiment, and other allied behavioral tendencies. This study is focused on analyzing the job satisfaction of banking employees on the basis of the working environment, cooperation among employees, training and promotion and salaries. Employees of Nepalese commercial banks were selected using a convenience sampling method for the study. A total of 112 respondents were selected to sample the employees of banks located in Kathmandu, Lalitpur, and Bhaktapur. The descriptive, as well as analytical research designs were used to analyze and draw a conclusion about the job satisfaction of bank employees. The self-structured questionnaire has been used. The major influencing factors for job satisfaction were salary, followed by training and promotion, working environment, and cooperation among them.
\end{abstract}

Keywords: Job satisfaction, employees, working environment, cooperation, training and promotion, and salary.

\section{Introduction}

Hoppock introduced the term "Job satisfaction" in 1953 in his book job satisfaction. He defined job satisfaction as "Any combination of psychological physiological and environmental circumstances that makes a person say I am satisfied with the job". Human resources are regarded as the human capital of the organization. Therefore, the utilization of various resources can help to achieve specific goals based on the performance of human capital. In this context, job satisfaction is importance for the growth of any organization. It refers to the extent of positive feeling or attitudes of persons towards their job, which serves as a motivational factor to work. It is compound of emotions, feelings, beliefs, sentiments, and other allied behavioral tendencies. Employees Job satisfaction is a measure of persons' contentedness with their job, whether or not they like the job or individual aspects or facets of jobs, such as nature of work or supervision. It can be measured in cognitive, affective, and behavioral components of the persons. When persons say that they have high job satisfaction, it means that they really like their job, feels good about it and value their job dignity. It is a general attitude towards one's jobs, the difference between the number of reward persons receive and the amount they believe should receive. Human resources are regarded as the backbone of any organization. It means work cannot be performed without human resources so, satisfaction of them is very important. The human resource will be more satisfied if they get what they expect. Job satisfaction relates to the inner feelings of human resources. 
Banking is a service industry for which human capital is very much paramount. Nowadays, the banking sector is experiencing the changing performance of its human resources. However, the sublime performance of the human resources of bank depends on their job satisfaction. So, job satisfaction is nothing but the degree or the extent to which one likes or dislikes the job.

Locke (1976) concluded that the job satisfaction as a positive emotional feeling attributed to the appraisal of one's job or job experiences. The term job satisfaction refers to the attitude and feelings of employees about their work.

Armstrong (2006) found that positive and favorable attitudes towards the job indicate the job satisfaction similarly negative and unfavorable attitudes towards the job indicate job dissatisfaction. Job satisfaction has a multi-dimensional facets consisting of attitudes towards salary, promotion, working experience, working environment, nature of work etc. It is considered as a crucial for the organizational effectiveness. It is related with human resource management. Therefore, the level of job satisfaction of the human resources has a crucial role to play for the retention and attraction of the competent human capital in the organization. Currently, job satisfaction has become an important issue in the organization.

Kaliski (2007) job satisfaction is a achievement and success of human resources on their job. It is generally perceived to be directly linked to productivity as well as to their personal well-being. It implies on doing the job enjoys, and well being rewarded for their efforts. Job satisfaction happens when a human resource feels job stability, career growth and a comfortable work life balance. This implies that the human resource is having satisfaction at job as the work meets the expectations of the individual.

George and Jones (2008) job satisfaction is the collection of feeling and beliefs that human resources have about their current job. The degree of job satisfaction can be ranged from extreme dissatisfaction to extreme satisfaction. Human resources also can have attitude about various aspects of their job such kind of work they do, their coworkers, supervisors, subordinates and their pay.

Aziri (2011) the efficiency and effectiveness of organizations are concerned with the employees and their job satisfaction is regarded as the main determinant. The new managerial paradigm of human resources should be treated and considered primarily as human beings that have their own wants, needs, and personal desired is a good indicator for the importance of job satisfaction.

Panghal (2013) the banks expect to improve human resources satisfaction is a key component of stakeholder value creation process to make a win-win environment for all. So, in this competitive environment, the critical thing is to know the views of human resource toward the job and measure the level of satisfaction with various aspects. Efficient human resource management and maintain higher job satisfaction of human resources that determine not only the performance of the bank but also affect the growth and performance of the entire economy. So, for the success of banking depends on the management of human resources effectively and to find whether they are satisfied or not is very important. The satisfied human resources can perform their work with commitment and can help to create a positive image of the bank.

Sharma et.al (2014) concluded that an increase in level of financial benefit, performance appraisal system, promotional strategies, training, and development program improves the overall satisfaction of human resources.

Vrinda, and Jacob (2015) examined the impact of job satisfaction on their job performance. This study concluded that the satisfying event of human resources in the job, why they continue or leave the bank that also a determination of job satisfaction. The findings of the study are job satisfaction and their performance was found to be even higher for professional jobs than for a less complex job.

Romel (2017) when analyzing job satisfaction, the human resources should be satisfied. Therefore, job satisfaction of human resource is the major concern for the success of the bank and also considered as a topic for the discussion in this paper. This can be defined as an individual general attitude toward his or her job. It plays an important role in improving the financial standing of bank. Job satisfaction and morale is derived from and is caused by many inter-related factors. 
Vol. 4, No. 1

\section{Research Issues}

One of the main roles of human resource department is to ensure that human resources are sufficiently satisfied with their jobs. It is assumed that satisfied employees are thought to be more productive. On the other hand, if they are dissatisfied with their jobs, they are thought to be less productive and more prone to absenteeism and turnover. So, human resource development needs to measure human resources satisfaction and examine the relationship with productivity, absenteeism and turnover with regard to possible variables.

What are the most significant factors of influencing the satisfaction of the job that are highly perceived by human resources particularly in the context of Nepalese commercial banks? The government of Nepal adopted the liberal economic policy at the early of 1990; the trend of establishing banks had been growing. At present total 28 commercial banks are in operation. Banks are facing high competition due to the entry of new commercial banks, development banks, financial institutions, microfinance and cooperatives operating the same in urban areas. In this situation every banks need to focus on the best managing of human resources so as to ensure high job satisfaction for providing effective and quality services through their competent, committed and motivated psychology of human resource. The aggregate level of job satisfaction is the reflection of the effective management of resourceful humans. Hence, the study states that, the positions of overall job satisfaction levels of human resources working in Nepalese commercial banks.

The nature of the bank work involves meeting the customer requirements, handling money transactions and maintenance of records. It is really hard to care about the demand of customers.

- The human resource of bank should perform their work with a smile?

- Is the quality of service to greatly depend on the total effort of the bank employees?

- Are the satisfied employees the backbone for the successful functioning of the bank?

- Is the level of job satisfaction of the employees depends on many factors?

Sumitha and Padmaja (2017) job satisfaction of human resources is more important because there have various aspects on the job that are highly attractive and lead to satisfaction of the job or lead to dissatisfaction.

\section{Objectives of the study}

The primary objective of this study is the major specific factors influencing the job satisfaction of human resources of a commercial bank in Nepal. However, the subsidary objectives are as follows:

- To study the job satisfaction of human resources in relation to working environment.

- To analyze the job satisfaction of human resources with respect to the compensation and salary.

- To study the job satisfaction of human resources with cooperation and relation.

- To explore the job satisfaction of human resources with respect to training and promotion.

\section{Hypothesis}

The level of job satisfaction of human resources of bank is based on the following variables like working environment, cooperation, training and promotion, and salary and compensation.

H1: The level of job satisfaction significantly depends on the working environment.

$\mathrm{H} 2$ : The level of job satisfaction significantly depends on the cooperation among staffs.

H3: The level of job satisfaction significantly depends on the training and promotion.

H4: The level of job satisfaction significantly depends on the salary and compensation.

\section{Research Methodology}

This study is entirely based on primary sources of data. Human resources from all the commercial banks are part of the study. The non-probability i.e. convenient sampling method has been employed to collect the data. The data has been collected from the human resources of Nepalese commercial banks 
NCC JOURNAL - 2019

through a self-structured questionnaire. The 160 questionnaires were distributed among the human resources of bank in Kathmandu, Lalitpur, and Bhaktapur but only 112 questionnaires were received as sample. The descriptive as well as analytical research designs have been used to analyze the sample.

Multiple regression models: $\quad \mathbf{Y}=\beta_{0}+\beta_{1} \mathbf{X}_{1}+\boldsymbol{\beta}_{2} \mathbf{X}_{2}+\beta_{3} \mathbf{X}_{3}+\beta_{4} \mathbf{X}_{4}+\ldots \ldots \ldots+\varepsilon i$

The coded data are analyzed by using SPSS V.23 software (Statistical Packages for the Social Scientist). The summary results of summated scale of job satisfaction using descriptive and inferential statistics.

\section{Results:}

\section{Demographic results}

Gender:

\begin{tabular}{|l|c|c|}
\hline Gender & No of employees & Valid Percentage \\
\hline Female & 74 & 69.6 \\
\hline Male & $\underline{34}$ & $\underline{30.4}$ \\
\hline & 108 & 100.0 \\
\hline
\end{tabular}

Source: Field survey, 2017

The table reveals that the majority of the respondents are female employees' i.e 69.6 percent and male employees are 30.4 percent and 4 are missing. This states that the female are more attracted towards job rather than male.

Marital Status:

\begin{tabular}{|l|c|c|}
\hline \multicolumn{1}{|c|}{ Particulars } & No of employees & Valid Percentage \\
\hline Unmarried & 41 & 38.0 \\
\hline Married & 60 & 55.5 \\
\hline Divorce & $\underline{07}$ & $\underline{06.5}$ \\
\hline & 108 & 100 \\
\hline
\end{tabular}

Source: Field survey, 2017

This table presents that the 55.5 percent employees were married followed by 41 percent and 6.5 percent unmarried and divorce respectively. This implies that the banking job has become huge popular among unmarried in comparison to the married persons.

Job Types:

\begin{tabular}{|l|c|c|c|c|}
\hline \multicolumn{1}{|c|}{ Particulars } & Female & Valid Percent & Male & Valid Percent \\
\hline Operating Level & 61 & 82.4 & 16 & 48.5 \\
\hline Asst. Manager & 9 & 12.2 & 11 & 33.3 \\
\hline Manager & $\underline{4}$ & $\underline{05.4}$ & $\underline{06}$ & $\underline{18.2}$ \\
\hline Total & 74 & 100 & 33 & 100 \\
\hline
\end{tabular}

Source: Field Survey, 2017

This table demonstrates that majority of females i.e. 82.4 percent are found to be involved in operating level followed by 5.4 percent in managers' level. Similarly 48.8 percent male employees are in operating level and 18.2 percent are in managers' level. 
Vol. 4 , No. 1

\begin{tabular}{|l|c|c|c|c|}
\hline \multicolumn{5}{|c|}{ Education Level: } \\
\hline Particulars & Female & Valid Percent & Male & Valid Percent \\
\hline Graduate & 35 & 46.1 & 10 & 30.3 \\
\hline Master or above & 27 & 35.5 & 14 & 42.4 \\
\hline Total & $\underline{14}$ & $\underline{18.4}$ & $\underline{09}$ & $\underline{27.3}$ \\
\hline
\end{tabular}

Source: Field survey, 2017

So far the level of education is concerned; the table reveals that 46.1 percent female employees are recorded as under graduate followed by 18.4 percent as master level or above. Likewise, 42.4 percent employees have completed graduate level and 27.3 percent employees are master level or above.

II. Descriptive Statistics of dependent variables (Job satisfaction):

\begin{tabular}{|l|c|c|c|}
\hline \multicolumn{1}{|c|}{ Sex } & Mean & Standard Deviation & Coefficient of Variation \\
\hline Female & 5.76 & 4.44 & 0.193 \\
\hline Male & 5.77 & 4.74 & 0.205 \\
\hline Total & 5.77 & 4.52 & 0.196 \\
\hline
\end{tabular}

The average job satisfaction of female employees is 5.76 and male employees are 5.76 out of total job satisfaction score 9. This describes the 64.1 percent of job satisfaction described by four predictors and remaining by other factors. Similarly, standard deviation has been used in the study to measure the absolute variability of a distribution. The standard deviation of male and female employees is 4.44 and 4.74 respectively.

III. Descriptive Statistics of independent variables:

\begin{tabular}{|l|c|c|c|c|c|}
\hline \multicolumn{1}{|c|}{ Particulars } & Mean & $\begin{array}{c}\text { Standard } \\
\text { Deviation }\end{array}$ & $\begin{array}{c}\text { Valid } \\
\text { Frequency }\end{array}$ & $\begin{array}{c}\text { Missing } \\
\text { Frequency }\end{array}$ & $\begin{array}{c}\text { Coefficient } \\
\text { of variation }\end{array}$ \\
\hline Working Environment & 4.52 & 1.626 & 108 & 4 & 0.36 \\
\hline Co-operation with employees & 7.56 & 1.608 & 108 & 4 & 0.21 \\
\hline Training \& Promotion & 5.45 & 2.038 & 105 & 7 & 0.37 \\
\hline Salary & 5.66 & 1.908 & 107 & 5 & 0.34 \\
\hline
\end{tabular}

This table shows that the predictor cooperation with employees' contribute maximum and minimum is working environment for the job satisfaction.

IV. Karl Pearson's correlation coefficient

\begin{tabular}{|l|c|c|c|c|c|}
\hline \multicolumn{1}{|c|}{ Items } & J. Satisfaction & W. Environment & Cooperation & Training \& Pro & Salary \\
\hline J. Satisfaction & 1 & $0.597^{* *}$ & $0.539^{* *}$ & $0.670^{* *}$ & $0.700^{* *}$ \\
\hline W. Environment & & 1 & $0.310^{*}$ & 0.119 & $0.199^{*}$ \\
\hline Co-operation & & & 1 & 0.041 & 0.147 \\
\hline Training \& Pro. & & & & 1 & $0.413^{* *}$ \\
\hline Salary & & & & & 1 \\
\hline
\end{tabular}

${ }^{* *}$ Correlation is significant at the 0.01 level ( 2 tails)

* Correlation is significant at the 0.05 level (2 tails) 
The correlation coefficient shows the relationship between job satisfaction and the variables. The value of correlation coefficient lies in between -1 to +1 . The -1 is the perfectly negatively correlation between variables and +1 is the perfectly positively correlation between the variables.

The matrix shows that there is positive significant relation between the job satisfaction and working environment, cooperation among employees, training and promotion, and salary. This shows that the high job satisfaction variable is salary and least job satisfaction variable is cooperation among employees.

\section{Casual comparative analysis (Regression Analysis):}

The linear regression analysis is a basic and commonly used type of predictive analysis. It is set of statistical processes for estimating the dependent variables on the basis of independent variables. It includes many techniques for analyzing several variables, when the focus is on the relationship between a dependent variable and one or more independent variables. The effect of job satisfaction:

$$
\begin{aligned}
& \mathbf{Y}=\beta 0+\boldsymbol{\beta}_{1} \mathbf{X}_{1}+\boldsymbol{\beta}_{2} \mathbf{X}_{2}+\boldsymbol{\beta}_{3} \mathbf{X}_{3}+\boldsymbol{\beta}_{4} \mathbf{X}_{4}+\ldots \ldots \ldots+\varepsilon i \\
& \text { Where, } Y=\text { Job Satisfaction, } \\
& \beta 0=\text { Constant parameter } \\
& \mathrm{X} 1=\text { working environment } \quad \mathrm{X} 2=\text { Cooperation among employees } \\
& \mathrm{X} 3=\text { Training and promotion } \quad \mathrm{X} 4=\text { Salary }
\end{aligned}
$$

\begin{tabular}{|c|c|c|c|c|c|c|c|}
\hline \multicolumn{8}{|c|}{ Summary of Regression Analysis } \\
\hline $\mathrm{R}=$ & 0.923 & $\mathrm{R}^{2}=$ & 0.852 & $\mathrm{~F}=$ & 121.87 & $\mathrm{P}=$ & 0.000 \\
\hline$\beta 0=$ & 3.470 & $t=$ & 2.725 & $\mathrm{P}=$ & 0.000 & & \\
\hline$\beta 1=$ & 0.991 & $t=$ & 6.773 & $\mathrm{P}=$ & 0.000 & & \\
\hline$\beta 2=$ & 1.162 & $t=$ & 7.796 & $\mathrm{P}=$ & 0.000 & & \\
\hline$\beta 3=$ & 0.979 & $t=$ & 8.359 & $\mathrm{P}=$ & 0.000 & & \\
\hline$\beta 4=$ & 1.187 & $t=$ & 9.088 & $\mathrm{P}=$ & 0.000 & & \\
\hline \multicolumn{8}{|c|}{$\mathrm{VIF}=1$} \\
\hline
\end{tabular}

The correlation coefficient of 0.92 demonstrates high degree of association between job satisfaction and its determinants included in the model. The coefficient of determination of 0.852 indicates that around 85 percent of the variation explained in job satisfaction is explained by the variables incorporated in the model. It means that this analysis describes the dependent variables positively explained by the independent variables. The Variance Inflated Factor (VIF) $=1<10$ this states that there is no multi co-linearity and the model is fit. The calculated value of $F$ statistics is greater than tabulated critical value, similarly $p$ value $=0.000<0.01$. So, there is significance and positive impact on the independent variables to the dependent variable. The most powerful predictor is salary coefficient and less powerful predictor is training and promotion. It means, the job satisfaction is significantly depended on the four independent variables. Hence, the prior hypothesis has been accepted.

\section{Conclusion}

The study concerned on job satisfaction of Nepalese commercial banks' employees. The job satisfaction is directly depended on the different factors. The basic depended factors are working environment, cooperation among employees, training and promotion, and salary. These factors only satisfied the employees by 64.1 percent and rest 35.9 percent other factors may satisfy them. The job satisfaction was analyzed on the basis of gender, marital status, job type, educational level, and working 
Vol. 4, No. 1

environment, cooperation among employees, training and promotion, and salary. The insights gained by this analysis have brought out areas of improvement and has given a clear path to the management to improve the job satisfaction of employees of Nepalese commercial bank. The study has a broader appeal and can be extended to all commercial banks and financial institutions to gain helpful insights into job satisfaction of the employees.

\section{References}

Armstrong, M. (2006). A handbook of human resource management practice. London: Kogan Sage Publishing, Vol.19, Issue 5

Aziri, B. (2011). Job satisfaction: A literature review. Management Research and Practice, Vol.3 (4), Pp. 77-86

George, J. M. \& Jones, G. R. (2008). Understanding and managing organizational behavior (5 Ed.). New Jersey: Pearson/Prentice Hall.

Hoppock, R. Job Satisfaction (New York: Harper \& Row, 1935).

Kaliski, B. S. (2007). Encyclopedia of business and finance (2 ${ }^{\text {nd }}$ Ed.). Detroit: Thompson Gale.

Locke, E. (1976). What is job satisfaction? Organizational behavior and human performance, 4, pp 309-336. Pearson publication Pvt. Ltd.

Panghal, S. (2013). Factors influencing job satisfactions of banking sector employees in India. International Journal of New Innovations in Engineering and Technology. Vol. 3

Romel,M.(July,2017): Factors affecting “job satisfaction” in commercial banks(FINTECH)

Sharma A. ET. al. (Sept, 2014). A comparative study of sleep habits among medical and non-medical students in Saifai, Itawah. International journal community medical public health. Vol 5 pp 9-16

Sumitha, C. \& Dr. Padmaja, R. (July 2017). A study on job satisfaction of bank employees (with special reference to Indian bank, Vellore city). International Journal of Research Granthaalayah, Vol. 5, Issue 7.

Vrinda, N.N. \& Jacob, A. (2015). The Impact of job satisfaction and performance, International journal in Commerce, IT, and Social science. Vol. (2) pp 27-37. 